DOI 10.18551/rjoas.2019-07.04

\title{
RELATIONSHIP BETWEEN CONSUMER RESPONSE AND SCIENCE AND TECHNOLOGY IMPLEMENTATION AT HIJAB SMES IN GRESIK
}

\author{
Surjanti Jun*, Soesatyo Yoyok \\ Department of Economic Education, Faculty of Economics, University of Negeri Surabaya, \\ Indonesia \\ Sanaji \\ Department of Management, Faculty of Economics, University of Negeri Surabaya, \\ Indonesia
}

Wibawa Setya Chendra

Technical Faculty, University of Negeri Surabaya, Indonesia

*E-mail: junsurjantiunesa2018@gmail.com

\begin{abstract}
To increase its potential, hijab SMEs in Gresik have carried out various efforts, one of which is by implementing science and technology in their business activities. Although it has not been carried out perfectly, the results of implementing science and technology have significantly improved Hijab SMEs. The success in business can be seen from how consumer response to Hljab SMEs products. This study is exploratory research using a qualitative approach. The subjects were consumers from seven Hijab SMEs in Gresik with a research focus on how consumers respond to products produced by Hijab SMEs. Data were collected using questionnaires and observations to determine consumer responses of the Hijab SMEs products. Data were analyzed using Miles and Huberman techniques with four criteria attached, namely: Poor, Adequate, Good, and Very Good. The results indicate that the consumer response has increased especially after the Hijab SMEs implemented science and technology. Significantly, this study can also be a reference for studies on SMEs especially regarding the economic state and its development.
\end{abstract}

\section{KEY WORDS}

Consumer response, Hijab SMEs, science, technology.

Resource Dependence Theory is a theory that links organizational resources with their external resources. Pfeffer \& Salancik (1978) explained how to ensure the survival of an organization by minimizing the situation of uncertainty and dependence and the characteristics of an organization as an open system, depending on contingencies in the external environment (Dalke, 2015). This dependence encourages business organizations to carry out strategies for external cooperation [(Thompson; 1967) (Thompson \& McEwen; 1958)] or conduct inter-organizational relationships (Pfeffer \& Salancik, 1978). Hijab SMEs in Gresik have carried out various forms of cooperation synergy in both internal and external production. Although it has high potential, the efforts to develop the hijab industries in Gresik are less than optimal due to some organizational weaknesses in the ownership of business resources. Business resources generally include tangible resources and intangible resources (Ismail, et. al, 2012). The Head of Diskoperindagkop of Gresik (2014) mentioned that problems occur in Hijab SMEs in Gresik mainly due to the less optimal of product qualities (hijab stitching). Another problem faced was a market decline due to the dense competition and the design quality of fashionable hijab.

Perception is a process by which people choose, regulate, and interpret sensations, namely the direct response of sensory receptors (such as the eyes, ears, nose, mouth, and fingers) to basic stimuli such as light, color, smell, texture, and sound (Madichie, 2012). The study of perceptions focuses on what we add to the basic sensations in interpreting the 
stimuli received. Each individual interprets the meaning of stimulus to be consistent with their individual biases, needs, and personal experiences. There are three stages in interpreting stimulus (stimulation), namely exposure, attention, and interpretation to form the perception process. Perception will greatly influence how an individual responds to things perceived. If the perception is good, the response shows definitely good as well; in contrary, when it gives bad vibes, the response will be severe. One of the biggest problems faced by most companies is the quality of product images to the public. Several studies conducted related to this problem, one of which is the study of consumer perceptions of cars produced domestically or abroad. To create a good consumer perception, American car makers design not only good products that refer to consumer demand based on their likes and dislikes, but also advertisements that persuade consumers to choose products. Consumer perception, on the other hand, is described as acting and reacting to what someone sees (Kotler et al. 1998, p. 187). In bringing together two concepts, it can be said here that - advertising is the driving force (Akaka \& Alden, 2010), which is responsible for shaping consumer perceptions and encouraging behavioral responses (Jones et al., 2010).

The concept of Efficient Consumer Response (ECR) was introduced in 1992 as a result of competition from alternative store formats that highlighted large inefficiencies in the supermarket industry and its supply chain (Bhutta, Huq, \& Maubourguet, 2002). A study conducted on customer response shows that fast and accurate information flow through the supply chain enables suppliers and distributors to anticipate demand requirements that are far more accurate than the current system (Salmon Associates, Inc., 1993).

\section{LITERATURE REVIEW}

This study is based on empirical evidence on how consumer responses are influenced by the results of the implementation of science and technology carried out by the business actors, especially SMEs. A number of empirical studies involved with advertising mentioned two theories that generally appear in relation to consumer perceptions are cognitive theory and effective theory [(Park \& McClung, 1985) (Park \& Young, 1986) (Gyo-Lee \& Thorson, 2009)]. Cognitive involvement refers to reactions related to thoughts generated by stimuli (Blackwell, Miniard \& Engel, 2001) while effective involvement consists of feelings and arousal caused by stimuli (Dubé, Cervellon, \& Jingyuan 2003; Yoo \& Maclnnis, 2005). Ahuvia (2005) suggests that the relationship of an individual with any object (consumption) can involve feelings of positive effects, as well as identification. The implication for the research of Gresik UKM hijab is that in the future the SMEs, especially Hijab SMEs, are expected to increase the level of product sales after SME players obtain product evaluation information provided by consumers to improve products in accordance with information about consumers' perceptions of hijab. This study is a series of previous studies conducted by the research team (Surjanti et al.) and it also reinforced the basis of the proposal for studies and research in the Hijab SMEs in Gresik.

Consumer response is positive or negative feedback received by a company for its products, services, or business ethics. Consumer responses can be in term of purchasing decision or reviews to products produced or offered by the company. According to Pluzinski \& Qualls (1986), there are three traits that affect relationships in consumer responses including 1) iterations, 2) parallelism, and 3) complementarity. These three correspond and become theoretical limits for the relationship between effects, cognition, and conation. Consumer response cannot be separated from consumer perception and behavior, because both of these concerns how individuals make decisions on how to spend their resources (money, time, emotional involvement, etc.) to buy a product. According to Călin (2015), consumer response referring to their behavior and perception considers several dimensions, such as: what to buy (product), where to buy (location), and how often purchases are used (functions).

Hijab industry in Gresik is an industry based on local wisdom. Local wisdom is local potential such as natural, human, technological, and cultural resources [(Hariyadi, 2010) (Vanclay, 2011) (Aditiawati et al., 2016)]. In addition, local wisdom can also be interpreted as 
knowledge gained from experience, life views, knowledge, and life strategies and derived from ancestors (previous generation) [(Alfian, 2013) (Akhmar \& Syarifudin, 2007) (Phongphit \& Nantasuwan, 2002 ) (Kongprasetamon, 2007)]. Local wisdom in Gresik as "The City of Santri" (Rosidin, 2015) has a close relationship with the development of local industries in the area. It is evident in HR as how UKM Hijab craftsmen in Gresik work to hold the values of Islamic life, choose the type of business, and sewing skills that were passed down by previous generations. Hijab SMEs in Gresik has special characteristics compared to other SMEs, namely how they act more as distributors who collect the results of hijab craftsmen and sell them to consumers rather than acting as direct producers and sellers. This situation has a significant effect on weaknesses and advantages. Because SMEs will depend on small business units (craftsmen), the resulting products will have varying qualities in accordance with the capabilities of their respective craftsmen. This will be a significant obstacle to improving product quality because supervision and quality control are quite difficult to do. On the other hand, with a business model like this (as a distributor/collector) this business will form a unit of business which will help to improve the community's economy together. This condition will bring SMEs to an important role in the management of hijab business resources in Gresik Regency. This UKM has a large multiplier effect for the sustainability of the livelihoods of the surrounding population.

Habraken (1976) explained that the transformation process occurs 1) slowly (little by little), 2) unpredictably (when it starts and when it will end because it depends on the factors that influence it), 3) comprehensively and sustainably, and 4) subjectively (relating to the value system or emotion that exists in the community) (in Pakilaran, 2006). Implementing science and technology at work means utilizing science and technology such as knowledge, information, invention, technique, etc. to carry out the work specialization. According to Kamrowska-zaluska \& Soltys (2016), the work specialization process can be done through presenting the methods and results of the process, analyzing the evolution of the field of specialization; as well as identifying problems and challenges that occur during the process.

Furthermore, the implementation of science and technology in the industry means the changing process of knowledge and techniques in establishing and implementing existing cooperation. Collaboration can increase productivity as proved by Garcia, López-lópez, \& Acevedo-Triana (2016). They found that collaboration between researchers in Latin America possibly increased productivity in journal publications and the level of scientific knowledge of Latin American researchers. By this point, implementing science and technology in the cooperation strategy of the Hijab SMEs in Gresik is very possible to increase productivity (hijab) both quantity and quality especially if the Hijab SMEs consider consumer responses as a basis for creating in business policy.

\section{METHODS OF RESEARCH}

This study is a qualitative study using Mile \& Huberman technique on consumers of seven Hijab SMEs located in Banyuwangi Village, Manyar Sido Rukun Village, and Manyar Rejo Village. Each Hijab SMEs is a distributor who distributes production from \pm 30 craftsmen. Data were collected through questionnaires and observations. Furthermore, the data was formulated based on four variables of production, marketing, productivity, and networking. Mapping is carried out by providing criteria for size Poor (P), Adequate (A), Good (G) and Very Good (VG).

\section{RESULTS AND DISCUSSION}

Respondents were Hijab SMEs in Gresik who implemented science and technology. From the initial observation (data obtained from Diskopum Gresik), there are 8 SMEs with high potential to implement science and technology. From those eight, researchers conducted an initial selection to look for SMEs that implemented science and technology in their business activities and obtained seven SMEs for these criteria (see Table 1). This study then conducted a survey through questionnaires and interviews with the SMEs on how 
consumers responded after implementing science and technology on their business activities. In addition, researchers also conducted surveys to find out how their response.

Table 1 - Respondents of Hijab SMEs in Gresik

\begin{tabular}{|c|c|c|c|c|c|c|}
\hline \multirow{2}{*}{ No. } & \multirow{2}{*}{ Name } & \multirow{2}{*}{ Sex } & \multirow{2}{*}{ Address } & \multicolumn{3}{|c|}{ Labors } \\
\hline & & & & $\mathrm{F}$ & M & Total \\
\hline 1 & ALIFATUL HIDAYAH & $\mathrm{P}$ & Desa Banyuwangi & \pm 20 & 0 & 20 \\
\hline 2 & ANIS MUAFIAH (ANNISA) & $\mathrm{P}$ & Jl. Margojoyo RT: 11/04 Banyuwangi & \pm 20 & 0 & 20 \\
\hline 3 & MARYATI & $\mathrm{P}$ & Desa Gumeno Kampung Rambi RT: 13/05 Manyar & 5 & 0 & 5 \\
\hline 4 & SRI RESTUNI/Fahmi Collection & $P$ & Lebaksari Bungah Gresik & 25 & 0 & 25 \\
\hline 5 & Hj. ROICHAN & $P$ & sungonlegowo rt:002 rw:01, Bunga & \pm 20 & 0 & 20 \\
\hline 6 & KHAMIMAH & $\mathrm{P}$ & $\begin{array}{l}\text { JI. Wahidin Sudiro Husodo XIII C/5 RT: } \\
\text { 04/RW } 05 \text { Singorejo, Kebomas Gresik }\end{array}$ & 7 & 0 & 7 \\
\hline 7 & IZZAH & $P$ & Desa Banyuwangi & \pm 30 & 0 & 30 \\
\hline
\end{tabular}

Source: Data analysis.

The formulations are processed in the format of tables of potential and weaknesses, then separated in the potential table for four variables. The potential table is decrypted and is classified as Poor (P), Adequate (A), Good (G) and Very Good (VG) (see Table 2).

Table 2 - SMEs Potential on science and technology transformation

\begin{tabular}{|c|c|c|c|c|c|c|c|c|c|}
\hline Production & $\begin{array}{l}21 \text { indicators } \\
\text { criteria: } \\
16-21: V G \\
11-15: G \\
6-10: A \\
1-5: P\end{array}$ & $\begin{array}{l}10 \\
\mathrm{~A}\end{array}$ & $\begin{array}{l}16 \\
V G\end{array}$ & 12 & $\begin{array}{l}14 \\
G\end{array}$ & $\begin{array}{l}13 \\
G\end{array}$ & $\begin{array}{l}13 \\
G\end{array}$ & $\begin{array}{l}17 \\
G\end{array}$ & $\begin{array}{l}\text { Conclusion: } \\
\text { R2 and R7 show best } \\
\text { performance in } \\
\text { production }\end{array}$ \\
\hline Marketing & $\begin{array}{l}4 \text { indicators } \\
\text { criteria: } \\
4: V G \\
3: G \\
2: A \\
1: P\end{array}$ & $\begin{array}{l}2 \\
A\end{array}$ & $\begin{array}{l}4 \\
V G\end{array}$ & A & $\begin{array}{l}4 \\
V G\end{array}$ & $\begin{array}{l}4 \\
V G\end{array}$ & $\begin{array}{l}4 \\
V G\end{array}$ & $\begin{array}{l}4 \\
V G\end{array}$ & $\begin{array}{l}\text { Conclusion: } \\
\text { R1 and R3 show good } \\
\text { performances in } \\
\text { marketing, while others } \\
\text { show adequately }\end{array}$ \\
\hline Productivity & $\begin{array}{l}17 \text { indicators } \\
\text { criteria: } \\
13-17: V G \\
9-12: G \\
5-8: A \\
\ldots-4: P\end{array}$ & $\begin{array}{l}6 \\
A\end{array}$ & $\begin{array}{l}6 \\
\text { A }\end{array}$ & 5 & $\begin{array}{l}7 \\
\text { A }\end{array}$ & $\begin{array}{l}6 \\
\text { A }\end{array}$ & $\begin{array}{l}9 \\
G\end{array}$ & $\begin{array}{l}14 \\
V G\end{array}$ & $\begin{array}{l}\text { Conclusion: } \\
\text { Only R7 has the best } \\
\text { performance in } \\
\text { productivity, others are } \\
\text { only categorized good }\end{array}$ \\
\hline Networking & $\begin{array}{l}9 \text { indicators } \\
\text { criteria: } \\
7-9: V G \\
5-6: G \\
3-4: A \\
\ldots-2: P\end{array}$ & $\begin{array}{l}4 \\
\mathrm{~A}\end{array}$ & $\begin{array}{l}4 \\
\text { A }\end{array}$ & 3 & $\begin{array}{l}3 \\
A\end{array}$ & $\begin{array}{l}5 \\
G\end{array}$ & $\begin{array}{l}4 \\
\mathrm{~A}\end{array}$ & $\begin{array}{l}5 \\
G\end{array}$ & $\begin{array}{l}\text { Conclusion: } \\
\text { R5 and R7 has good } \\
\text { performance, while } \\
\text { others only show } \\
\text { adequately in } \\
\text { networking; this is } \\
\text { mainly due to } \\
\text { insignificant results } \\
\text { obtained according to } \\
\text { the respopndent }\end{array}$ \\
\hline
\end{tabular}

From data, conclusions are drawn on how consumer responses affect the SMEs potential. Table 2 shows that there are SMEs who still have weaknesses in implementing science and technology. However, R7 has implemented science and technology on the four variables almost comprehensively (averagely Very Good), on the contrary, R1 has done them less comprehensive (averagely Adequate).

Based on market analysis, several aspects that affect consumers' responses of SMEs' products are business locations, technology use in business activities, marketing activities, and business networks. From the business location, R2, R4, and R7 arranged the business location and store layout which are convenient for customers. This decision affects the 
selling points because customers prefer comfortable and easy to access place before buying products. The technology implementation in industrial activities is carried out by procuring production machinery (from design to packaging), surveillance cameras, and computers or the internet for marketing and expansion of industrial networks. In designing products, technology is employed as well (all R stated that they have made, developed, and introduced designs that use machinery or technological devices). These activities affect the quality of the products and, off course, lead to consumers satisfaction. Camera surveillance help to control quality in the production process because it ensures the stability of the production process. However, of the seven respondents, only R7 implemented science and technology by using surveillance (CCTV) during the production process and quality control from procuring raw materials, during processes, until the final product.

In the marketing, all respondents rely on consumer responses before carrying out the production process, so almost all Hijab SME products only respond to customer demand for production, yet R7 not only responds to consumers demand but also observes the market. From these, it is clearly seen that Hijab SMEs in Gresik only depend on existing customers; they mostly experience difficulties in business development because new prospective customers do not always have the same tastes as the existing ones. In addition, the management budget (implementing a comprehensive production calculation model including marketing costs (advertising), production costs, and maintenance costs (after-sales service)) is only performed by R7, while other respondents only consider production costs without considering marketing as well as after-sales service costs. After-sales services greatly influence the decisions of consumers in buying products (product purchases). This is due to the security felt after making a purchase because if the purchased product does not meet with their wishes or if there is any damage, they could request for product replacement/return. Without budgeting, especially those involving marketing and after-sales services, Hijab SMEs tend to experience difficulties or losses when products are not sold. This risk has become a significant problem and has caused the hinder in the development of the Hijab SMEs in Gresik.

The last variable of the science and technology implementation in this study is networking. From the analysis, it was found that Hijab SMEs in Gresik did not carry out this activity (developing industrial networks) so the SMEs only had consumers limited to certain environments. This condition resulting in consumers outside the SMEs area does not know (yet) on the products produced by those Hijab SMEs in Gresik. This greatly influences the income of SMEs because the target consumers will be limited. In addition, when outside consumers do not have information on product produced by the Hijab SMEs, they will be reluctant to purchase them. By implementing science and technology, the Hijab SMEs possibly increased their sales output (SME income). For examples, during observation, the researchers found that the Hijab SMEs averagely got revenues IDR 120 million/month (R5 and R6) because both SMEs only adequately implement the science and technology in their industrial activities. While other SMEs (R1, R2, R3, \& R4) got revenues IDR 300 million/months due to their well-implemented science and technology. The highest revenue was obtained by R7 which reached IDR 392 million/month due to her best implementation of science and technology compared to other SMEs. This income clearly illustrates how consumer responses to products produced by SMEs who implemented science and technology in their industrial activities.

\section{CONCLUSION AND RECOMMENDATIONS}

Seven respondents (R1-R7) of the Hijab SMEs Gresik have implemented the science and technology, yet only R7 who implement them accordingly. However, there are areas where science and technology have not been best-implemented. Thus, it can be the basis for determining science and technology implementation policy in further research.

Consumer response, in this study, can be used as a benchmark for implementing science and technology implementation in Hijab SMEs. 
The better the consumer's response is, the higher the possibility of SMEs implements science and technology as a whole.

It is recommended that respondents (R1-R7) to carry out comprehensive implementation on science and technology, especially $R 1-R 6$, while $R 7$ is expected to increase the application of science and technology transformation and become a driver for other SMEs in the vicinity.

As implementing science and technology influences consumer response, it is expected that the Hijab SMEs actors to implement science and technology at whole.

Moreover, consumer responses can be used as a reference in improving the quality of the implementation of science and technology of Hijab SMEs so the progress and development of UKM Hijab can be achieved at the end.

\section{REFERENCES}

1. Adeyoyin, Samuel Olu. 2015. Effect of Job Specialization and Departementalization on Job Satisfaction among the Staff a Nigerian University Library, Library Philosophy and Practice, Jurnal, (Online), Paper 1295, dalam (http://digitalcommons.unl.edu/libphilprac/ 1295), diakses tanggal 4 Juni 2017.

2. Aditiawati, Pingkan, dkk. 2016. Pengembangan Potensi Lokal Di Desa Panawangan Sebagai Model Desa Vokasi Dalam Pemberdayaan Masyarakat dan Peningkatan Ketahanan Pangan Nasional, Jurnal Sosioteknologi, (Online), Vol. 5 No. 1 April 2016 page 59-67, dalam (https://media.neliti.com/media/publications/41739-IDpengembangan-potensi-lokal-di-desa-panawangan-sebagai-model-desa-vokasi-dalampe.pdf), diakses tanggal 7 Juni 2017

3. Agyekum, C. K., Huang Haifeng, \& Agyeiwaa, Amma. 2015. Consumer Perception of Product Quality. Microeconomics and Macroeconomics 2015, 3(2): 25-29. DOI: 10.5923/j.m2economics.20150302.01

4. Akaka, M. A., \& Alden, D. L. (2010) Global brand position and perceptions: International Advertising and Global Consumer Culture. Int. Journal of Advertising, 29(1), 37-56.

5. Beatrice, C. (2015). Cross-sectoral cooperation vs . cluster development at European level, 22(November 2014), 175-183. http://doi.org/10.1016/S2212-5671(15)00255-5

6. Bhutta, M \& Huq, Faizul \& Maubourguet, Francine. (2002). Efficient Consumer Response - Increasing Efficiency through. 10.1007/978-3-662-11377-6_12.

7. Călin, Floricica Mariana. (2015). Consumer Response to Product and Service Quality. Procedia - Social and Behavioral Sciences 187 (2015)526 - 531.

8. http://creativecommons.org/licenses/by-nc-nd/4.0/

9. Dalke, Vincent. (2015). The Resource Dependence Theory: Assessment and Evaluation as a Contributing Theory for Supply Management, Jurnal, (Online),IBA Bachelor Thesis Conference, July 2nd, 2015, Enschede, The Netherlands.

10. Garcia, A., López-lópez, W., \& Acevedo-triana, C. A. (2016). Cooperation in the Latin American behavioral sciences: Motivation, evaluation and difficulties. Suma Psicológica, 23(2), 125-132. http://doi.org/10.1016/j.sumpsi.2016.08.002

11. Guleria, P. Singh \& Sadawarti, Harsh. 2015. Survey on Advancements in Retail Sector and Its Future. International Journal of Computer Science Trends and Technology (IJCST) - Volume 3 Issue 3, May-June 2015.

12. Kamrowska-zaluska, D., \& Soltys, J. (2016). Process of Emergence of Smart Specialisation in Pomeranian Voivodeship in Poland. Procedia Engineering, 161, 19871995. http://doi.org/10.1016/j.proeng.2016.08.791

13. Kompas.com.6 Agustus 2012.5 Tantangan Indonesia Menjadi Pusat Busana Muslim Dunia, Berita, (Online), in

14. http://female.kompas.com/read/2012/08/07/15260768/5.Tantangan.Indonesia.Menjadi.Pu sat.Busana.Muslim.Dunia,diakses tanggal 1 Januari 2016.

15. Kompas.com. 27 November 2017. UMKM Masih Dibelit Masalah, Berita, (Online), dalam http://news.liputan6.com/read/2662988/umkm-masih-dibelit-masalah, diakses tanggal 27 Mei 2017. 
16. Kotler, Philip. 2005. Manajamen Pemasaran, Jilid 1 dan 2.Jakarta: PT. Indeks Kelompok Gramedia.

17. Kotler, P., Armstrong G., Brown, L., \& Adam, S. (1998). Marketing (4th edition). Sydney: Prentice-Hall.

18. Kurt Salmon Associates, Inc. (1993): Efficient Consumer Response: Enhancing Consumer Value in the Grocery. Industry, Food Marketing Institute, Washington, DC.

19. Minar, E. (2016). EU-China cooperation on regional policy \& cíková, 30-38. http://doi.org/10.1016/j.pisc.2015.11.007

20. Madichie, Nnamdi. (2012). Consumer Perception. Tata McGraw Hill, pp.154-175. Bloomsbury Institute London. https://www.researchgate.net/publication/328676646

21. Nishino, N., Okazaki, M., \& Akai, K. (2017). Technological Forecasting \& Social Change Effects of ability difference and strategy imitation on cooperation network formation: A study with game theoretic modeling and multi-agent simulation. Technological Forecasting \& Social Change. http://doi.org/10.1016/j.techfore.2017.02.008

22. Pluzinski, Carol \& Qualls, William J. (1986)."Consumer Response to Marketing Stimuli: the Relationship Between Affect, Cognition, and Behavior", in NA - Advances in Consumer Research Volume 13, eds. Richard J. Lutz, Provo, UT: Association for Consumer Research, Pp231-234.

23. http://www.acrwebsite.org/volumes/6494/volumes/v13/NA-13.

24. Pylak, K., \& Majerek, D. (2017). Identifying industries requiring spatial and sectoral relationships to develop: Do smart specializations always work? Procedia Engineering, 174, 1119-1127. http://doi.org/10.1016/j.proeng.2017.01.265

25. Raposo, M. L., Ferreira, J. J. M., \& Fernandes, C. I. (2014). Revista Europea de Dirección y Economía de la Empresa Local and cross-border SME cooperation: Effects on innovation and performance. Revista Europea de Dirección Y Economía de La Empresa, 23(4), 157-165. http://doi.org/10.1016/j.redee.2014.08.001

26. Rusu, M. (2013). Smart Specialization a Possible Solution to the New Global Challenges. Procedia Economics and Finance, 6(13), 128-136. http://doi.org/10.1016/S22125671(13)00124-X

27. Republika.co.id. 23 November 2016. UMKM Hadapi Tiga Masalah untuk Go Internasional, Berita, (Online), dalam http://www.republika.co.id/berita/koran/financial/16/11/23/ oh37o72-umkm-hadapi-tigamasalah-untuk-go-international, diakses tanggal 27 Mei 2017.

28. Rosidin. 2015. Nilai-nilai Kerukunan Dalam Kearifan Lokal Masyarakat Bawean Gresik, Jurnal Al-Qolam, (online), Vol. 21 No. 5 Juni 2015, (http://jurnalalqalam.or.id/index.php/ Alqalam/article/download/211/194), diakses tanggal 16 Juni 2017.

29. Sibirskaya, E., Stroeva, O., \& Simonova, E. (2015). The Characteristic of the Institutional and Organizational Environment of Small Innovative and Big Business Cooperation. Procedia Economics and Finance, 27(15), 507-515. http://doi.org/10.1016/S22125671(15)01028-X

30. Surjanti, Jun, dkk.2007.Analisis Karakteristik Produk Bordir Berdasarkan Kepuasan Konsumen sebagai Rintisan Pemberdayaan Sentra Industri Kecil di Jawa Timur (Studi Kasus di Sentra Industri Kecil Bordir Tanggulangin Sidoarjo. Surabaya: Lemlit Unesa. (Laporan Penelitian) Program Hibah DP2M Dikti Jakarta.

31. Surjanti, Jun. 2009. Model Peningkatan Pendapatan Nelayan dan Perluasan Lapangan Kerja melalui Pengembangan Produk Hasil Tangkapan Kelompok Tani "Rukun Nelayan" Paciran-Lamongan. Surabaya: Lemlit Unesa. (Laporan Penelitian) Program Stranas DP2M Dikti Jakarta.

32. Surjanti, Jun. dkk 2009.Model Peningkatan Pendapatan Nelayan Dan Perluasan Lapangan Kerja Melalui Pengembangan Produk Hasil Tangkapan Kelompok Tani "Rukun Nelayan" Paciran-Lamongan. Hasil Penelitian Stranas 2009 (Laporan Penelitian). Surabaya: Lemlit Unesa.

33. Surjanti, Jun. dkk 2010. Analisis Perluasan Lapangan Kerja Berdasarkan Minat Nelayan Pada Kelompok Tani "Rukun Nelayan". Proseding "Seminar Nasional Hasil-Hasil Penelitian.Lembaga Penelitian Universitas Negeri Surabaya. 
34. Surjanti, Jun, dkk. 2012. Pelestarian Motif Batik melalui Penguatan Produksi Printing Pada Usaha Batik Tulis Khas Pasuruan "Pendalungan". Surabaya: LPPM Unesa. (Laporan Penelitian) Program IPTEKDA Dikti Jakarta.

35. Surjanti, Jun. dkk.2014.Studi Persepsi dan Efektivitas Implementasi Tanggungjawab Sosial Perusahaan Untuk Pemberdayaan Masyarakat (Laporan Kerjasama Unesa - JOB PPEJ). Surabaya: LPPM Unesa.

36. Surjanti, Jun, dkk. 2014. Studi Persepsi dan Efektifitas Implementasi Tanggung Jawab Sosial Perusahaan untuk Pemberdayaan Masyarakat. Program kerjasana Unesa-JOB PPEJ. Surabaya: Unesa

37. Surjanti, Jun.2013.Pengembangan Desain Bordir Khas Sidoarjo melaluiPenguatan Karakteristik Produk Berdasarkan Persepsi Konsumen (Tahun ke-1). Surabaya: LPPM Unesa. (Laporan Penelitian) Program MP3EI Th. 1 DP2M Dikti Jakarta.

38. Surjanti, Jun.2014.Pengembangan Desain Bordir Khas Sidoarjo melaluiPenguatan Karakteristik Produk Berdasarkan Persepsi Konsumen (Tahun ke-2). Surabaya: LPPM Unesa. (Laporan Penelitian) Program MP3EI Th. 1 DP2M Dikti Jakarta.

39. Surjanti, Jun. dkk.2015.Pengembangan Produk Unggulan Daerah melalui Pendampingan Kelompok Bisnis Makanan Berbahan Dasar Ikan di Kabupaten Lamongan (Tahun ke1).Surabaya: LPPM Unesa. (Laporan Penelitian) Program MP3EI Th. 2 DP2M Dikti Jakarta.

40. Surjanti, Jun. dkk.2016.Pengembangan Produk Unggulan Daerah melalui Pendampingan Kelompok Bisnis Makanan Berbahan Dasar Ikan di Kabupaten Lamongan(Tahun ke2).Surabaya: LPPM Unesa. (Laporan Penelitian) Program MP3EI Th. 2 DP2M Dikti Jakarta.

41. Suwarman, Ujang. 2011. Perilaku Konsumen: Teori dan Penerapannya dalam Pemasaran. Jakarta: Ghalia Indonesia.

42. Tjiptono, Fandy \& Chandra, Greogerius. 2012. Pemasaran Strategik: Mengupas Pemasaran Strategik, Branding Strategy, Customer Satisfaction, Strategi Kompetitif, hingga e-Marketing. Yogyakarta: Andi.

43. Vanclay, Frank. 2011. Endogenous Rural Development from a Sosiological Prespective. Endogenous Regional Development: Prespective, Measurement, and Empirical Investigation, dalam https://books.google.co.id/books?id=ULQBY|4t2fYC\&printsec=frontcover\#v=onepage\&q\& $\mathrm{f}=$ false, diakses tanggal 10 Juni 2017. 